Institute for Research on Poverty

Discussion Paper no. 1018-93

\title{
The Employment Effect in Retail Trade of California's 1988 Minimum Wage Increase
}

\author{
Lowell J. Taylor \\ Heinz School of Public Policy and Management \\ Carnegie Mellon University \\ Taeil Kim \\ Heinz School of Public Policy and Management \\ Carnegie Mellon University
}

September 1993

The first author gratefully acknowledges research support from the Institute for Research on Poverty, University of Wisconsin-Madison. We thank David Card, John Engberg, and Seth Sanders for helpful comments. 


\begin{abstract}
In this paper, we study the outcome of an unusually clean natural experiment--California's large minimum wage increase of 1988. Two different approaches to evaluating the experiment result in the same conclusion: the textbook analysis of minimum wages holds true. In particular, we find that employment growth in California's low-wage retail trade industry was slowed by the minimum wage increase.
\end{abstract}




\section{The Employment Effect in Retail Trade of California's 1988 Minimum Wage Increase}

Since the passage of the Fair Labor Standards Act of 1938, minimum wage laws have represented one of our country's most prominent labor market interventions. Subsequent to the establishment of the Act, a number of amendments have raised the federal minimum. Most recently, after almost a decade with no changes, the federal minimum increased from $\$ 3.35$ to $\$ 3.80$ on April 1 , 1990 , and one year later to $\$ 4.25$. There appears to be broad support in the new Democratic administration for raising it still further. Some favor rather substantial increases. For instance, one proposal, forwarded by House Budget Committee Chairman Martin Olav Sabo, would boost the minimum wage to $\$ 6.50$ an hour.

Many policymakers are enthusiastic about increasing the minimum wage because they feel it will raise the earnings of low-wage workers while not greatly damaging their employment prospects. This view has been bolstered recently by a series of interesting and compelling empirical studies which call into question economists' conventional prediction--that an increase in the minimum wage moves equilibrium backward along the demand curve for labor, reducing the employment of low-wage workers. Each of these studies suggests that the most recent round of increases in the minimum wage in the United States in fact had little effect on employment among low-wage workers.

One study, by David Card (1992a), explored the consequences for teenage employment of California's minimum wage increase of July $1988 .{ }^{1}$ Card compared changes in teenage employment in California and in a group of southwestern and southern states from 1987 to 1989. Although the minimum increased in California during this period while remaining fixed in the other states, no impact was found on California's teenage employment. (Indeed the effect seemed to be the "wrong way": employment increased.) In a second study, Card (1992b) exploited regional variation in wages across the United States and found little evidence that recent increases in the minimum wage reduced 
low-wage employment. Lawrence Katz and Alan Krueger (1992) and Card and Krueger (1993), in studies of the fast-food industry, also detected little change in employment due to increases in the minimum wage. ${ }^{2}$

As the authors of these papers have suggested, the finding that minimum wage increases do not adversely affect employment indicates that economists should reevaluate the standard welfare analysis of minimum wage laws. The result also may indicate that low-wage labor markets are not well described by conventional models, and economists should consider alternatives to textbook theory in analyzing these labor markets. ${ }^{3}$

Because the most recent wave of empirical studies is important and perhaps somewhat controversial, and because much of the previous literature is equivocal, we have undertaken in this paper a new empirical evaluation of a recent increase in the minimum wage--California's substantial increase (from $\$ 3.35$ to $\$ 4.25$ ) in July 1988 . The increase of the minimum wage in California provides an especially clean "natural experiment" for evaluating the effects of a wage floor. We can think of California as a treatment group, and the rest of the nation as a control. Our focus is the effect of the wage change on employment in retail trade, a sector that employs a disproportionate number of low-wage workers. In particular, we seek to discover if the increase in the minimum wage resulted in systematic industry variation in employment growth and wage changes within the retail trade industry.

Using data from County Business Patterns (U.S. Department of Commerce, various years), we find evidence that is not at all ambiguous or sensitive to specification. This evidence is consistent with conventional theory. In evaluating the period March 1988-March 1989, we show that within retail trade, in those industries where the wage increased most rapidly in California relative to the rest of the country, relative employment growth fell.

We also pursue an alternative approach in studying the effect of the minimum wage increase. We note that within California there was substantial intercounty variation prior to the 1988 minimum 
wage increase. Retail trade wages in some (primarily urban) counties were rather high; in these counties an increase in the minimum could have little impact. Retail trade employees were initially paid substantially less in other (often rural) counties. Conventional theory suggests that employment would be adversely affected in these latter counties. Our empirical results are in accord with this prediction.

Interestingly enough, the magnitude of the effect of the minimum wage on employment growth estimated in our regressions is quite similar in the two approaches we take.

\section{RETAIL TRADE IN CALIFORNIA AND THE UNITED STATES, 1986-1989}

Our study focuses on employment in the retail trade industry. Studies concentrating on other industries may also prove useful, but the retail trade sector is of particular interest. Because wages paid by many employers in this industry are low, the minimum wage is particularly likely to present a binding constraint in this industry. Also, the retail trade industry is by far the largest employer of low-wage workers. Using CPS data, Card (1992a) estimated that in 1987 over 30 percent of California's workers in retail trade earned at least $\$ 3.35$ per hour but less than the new minimum, $\$ 4.25$. Moreover, nearly half of all workers who earned $\$ 3.35-\$ 4.24$ were employed in retail trade.

The years 1986 to 1989 represent an excellent period for investigating the independent effect of the imposition of a new minimum wage. During this time, inflation was very low, increasing only slightly toward the end of 1988 and into 1989. Overall unemployment in the mid to late 1980s was gradually declining as the national economy continued to recover from the recession of the early 1980s. Furthermore, rates of unemployment were similar in California and the United States as a whole. In 1988 and 1989 the unemployment rates in the United States were, respectively, 5.5 and 5.3. In California, the corresponding figures were 5.3 and 5.1. 
We use data from the County Business Patterns $(C B P)$ issued by the Bureau of the Census to track trends in employment and pay. These data indicate firms' payrolls (based on the Employer's Quarterly Federal Tax Return for the first quarter of the year, and the firms' total employment for a pay period including March $12 .{ }^{4}$ In the retail trade industry, trends in employment were quite similar in California and the United States as a whole over the 1986-1989 period. Table 1 presents a summary. The third row of this table shows that growth in retail trade employment was not much different in California than in the rest of the United States. Employment grew slightly less rapidly in California in 1986-87 and somewhat more rapidly in 1987-88. The 1988-89 employment trend, which reflects any effect of the 1988 increase in California's minimum wage, shows employment growing a little more slowly in California than in the United States.

Table 1 also presents statistics for the reported pay per person in the retail trade industry. Most notable is the fact that wages grew much more rapidly in California than in the rest of the United States from the first quarter of 1988 to the first quarter of $1989 .^{5}$ A natural explanation for this outcome is of course that the minimum wage increased in California (from $\$ 3.35$ to $\$ 4.25$ ) in July of 1988 , while the wage floor remained constant in nearly all other states. ${ }^{6}$

These observations are consistent with Card's (1992a) finding. While wages in retail trade did increase more in California than in the rest of the United States in 1988-89, presumably as a result of the new minimum wage law, employment was hardly affected. Growth in retail trade employment was a bit slower in California, but the magnitude of the deviation from the U.S. trend was small and no larger (in absolute terms) than in the previous two years.

It is hard to make a good argument based on the data in Table 1, however, because they are aggregate data and thus may smooth over any systematic employment effects that may exist. 


\section{TABLE 1}

Percentage Change in Employment and Wages in the Retail Trade Industry

\begin{tabular}{lcccccc}
\hline & \multicolumn{2}{c}{ Percentage Change in Employment } & \multicolumn{2}{c}{ Percentage Change in Wages } \\
\cline { 2 - 5 } & $1986-1987$ & $1987-1988$ & $1988-1989$ & $1986-1987$ & $1987-1988$ & $1988-1989$ \\
\hline California & 4.46 & 2.95 & 2.48 & 1.28 & 2.75 & 6.15 \\
United States & 5.00 & 1.98 & 2.88 & 0.99 & 3.62 & 3.83 \\
$\begin{array}{l}\text { Difference between } \\
\text { percentages }\end{array}$ & -0.54 & 0.97 & -0.40 & 0.29 & -0.87 & 2.32 \\
\hline
\end{tabular}

Source: County Business Patterns. 
Therefore we looked at disaggregated data on sectors within the retail industry to see if there was more to these findings than meets the eye. Table 2 presents statistics similar to those given in the bottom row of Table 1, but for 2-digit SIC industry classifications within retail trade. Although the differences regarding wages in each sector vary considerably, the picture is quite consistent. In nearly every sector, notably Eating \& Drinking places and General Merchandise stores, wages increased in California at a higher rate than in the country as a whole; in only one sector did wages rise more slowly in California. The figures concerning employment are more mixed: in three sectors, employment grew at a slower rate in California than in the United States, while in the other four sectors, employment increased at a faster pace. Moreover, the variation appears to be systematic: in industries in California that experienced the greatest relative growth in wages, employment suffered the greatest relative declines, and vice versa.

This observation casts some doubt on the argument that the minimum wage increase had no effect on retail trade in California, and suggests that further investigation is warranted.

\section{INTERINDUSTRY EFFECTS OF THE MINIMUM WAGE}

In the textbook model of the labor market, the relationship between wages and employment is simple: wages and employment are jointly determined by the supply of labor and labor demand. A regression of the form

$$
\Delta E_{i}=\beta_{0}+\beta_{1} \Delta w_{i}+u_{i}
$$

where $\Delta E_{\mathrm{i}}$ and $\Delta w_{\mathrm{i}}$ are changes in employment and wages, respectively, within an industry, therefore makes little sense. Employment is related to wages, but any changes in employment are the result of 
TABLE 2

Differences between the Percentage Growth in Wages and Employment in California and the United States: Retail Trade Industry, 1988-1989

\begin{tabular}{lcc}
\hline & Pay per Employee & Employment \\
\hline General Merchandise & 6.86 & -6.16 \\
Eating \& Drinking & 4.63 & -1.24 \\
Food Stores & 2.36 & -0.37 \\
Apparel \& Accessory & 2.31 & 1.19 \\
Building \& Garden Supplies & 0.77 & 3.15 \\
Furniture & 0.00 & 3.87 \\
Auto Dealer \& Service Stations & -1.56 & 2.02 \\
\hline
\end{tabular}

Source: County Business Patterns.

Notes: Column 1 gives the percentage change in pay per person in California minus the percentage change in pay per person in the United States, while column 2 is the difference in the percentage change in employment in California and the United States. These categories represent all retail trade industries except "Miscellaneous Retail." 
a shift in the supply curve or the demand curve (or both), and our regression will not distinguish between these.

For a year in which there is an exogenous shock to the wage, however, there may be some hope of identifying a demand curve for labor. Suppose, for instance, that changes in employment in a specific industry $i$ in California are due to movements along a conventional employment demand curve and possibly shifts in the demand curve as well. Assume that this can be represented by

$$
\Delta E_{c i}=\alpha_{0}^{c}+\alpha_{i}+\beta_{1} \Delta w_{c i}+u_{c i}
$$

where $E$ is the $\log$ of employment and $w$ the $\log$ of the wage, so that $\Delta E$ and $\Delta w$ are the percentage change in employment and wages respectively. Note that in (1), the percentage change in employment in industry $i$ is due not only to changes in the wage, but also to a California-specific change in the demand schedule, $\alpha_{0}^{C}$, and an industry-specific effect, $\alpha_{i}$.

If for the United States as a whole a similar demand curve pertains,

$$
\Delta E_{u s, i}=\alpha_{0}^{u s}+\alpha_{i}+\beta_{1} \Delta w_{u s, i}+u_{u i}
$$

we can subtract (2) from (1), giving

$$
\left(\Delta E_{c}-\Delta E_{u s}\right)_{i}=\beta_{0}+\beta_{1}\left(\Delta w_{c}-\Delta w_{u s}\right)_{i}+u_{i}
$$

where $\beta_{0}=\alpha_{0}^{C}-\alpha_{0}^{U S}$ and $u_{\mathrm{i}}=u_{\mathrm{ci}}-u_{\mathrm{ui}}$.

In a typical year, when there is no change in the minimum wage in either California or the rest of the nation, changes in wages will be the result of exogenous growth plus random shocks to 
specific industries. That is, the wage determination for industry $i$ in California and the United States respectively will be

$$
\begin{gathered}
\Delta w_{c, i}=\eta_{0}^{c}+\epsilon_{c i}, \\
\Delta w_{u s, i}=\eta_{0}^{u s}+\epsilon_{u i},
\end{gathered}
$$

so that

$$
\left(\Delta w_{c}-\Delta w_{u s}\right)_{i}=\eta_{0}+\epsilon_{i}
$$

with $\eta_{0}=\eta_{0}^{C}-\eta_{0}^{U S}$ and $\varepsilon_{\mathrm{i}}=\varepsilon_{\mathrm{ci}}-\varepsilon_{\mathrm{ui}}$. If we attempt to estimate equation (3) for such a year, the explanatory variable will be noise, and the result cannot be meaningfully interpreted. For the years 1988-89, however, there was an exogenous change in wages for low-pay workers, so $\Delta w_{\text {ci }}$ will be systematically related to industry characteristics within California. In particular, we would expect that industries with low initial wages would be most likely to be affected by the increase in the minimum wage. Similarly, because smaller firms may have higher noncompliance rates (Ashenfelter and Smith, 1979), or if they are more likely to use the subminimum provisions provided by the law, the average size of firms within an industry will be a determining factor in the effect on firms' wages of an increase in the wage floor. ${ }^{7}$ Thus, letting $\bar{w}_{i}$ be the mean wage for industry $i$ and $\bar{s}_{\mathrm{i}}$ be the $\log$ of the mean firm size within the industry, for the time frame 1988-89, equation (4) can be modified as 


$$
\begin{gathered}
\Delta w_{i}^{c}=\eta_{0}^{c}+\eta_{1} \bar{w}_{i}+\eta_{2} \bar{s}_{i}+\epsilon_{c i}, \\
\Delta w_{i}^{u s}=\eta_{0}^{u s}+\epsilon_{u i},
\end{gathered}
$$

so that

$$
\left(\Delta w_{c}-\Delta w_{u s}\right)_{i}=\eta_{0}+\eta_{1} \bar{w}_{i}+\eta_{2} \bar{s}_{i}+\epsilon_{i}
$$

Equations (3) and (5) then represent a system of identified equations for a period in which the minimum wage increased in California but not the rest of the nation. If the error terms in these two equations are uncorrelated, equation (3) can be estimated using OLS. But because the difference in wage changes in an industry are the result of the new minimum wage and also possibly industry-specific demand shocks in California, the error terms are likely to be correlated. In this latter case, consistent parameter estimates for equation (3) can be found using an IV estimator with $\bar{w}_{i}$ and $\overline{s_{i}}$ as instruments. ${ }^{8}$

Table 3 shows OLS and IV estimates of equation (3) using data for 3-4 digit sectors within the retail trade industry for the years $1985-86,1986-87,1987-88$, and 1988-89. In each case a weighted regression procedure is used, with weights given by employment in California in the 3-4 digit industry (although an unweighted procedure was found to yield the same results). ${ }^{9}$

The results of this exercise are striking. As expected, for the years 1985-86, 1986-87, and 1987-88, the regression results show little of interest; only one coefficient is significantly different from zero, and the typical value of the adjusted $R^{2}$ is low. Using the IV procedure, in particular, we cannot reject the null hypothesis of $\beta_{1}=0$ in any of our regressions. For $1988-89$, however, a 
TABLE 3

Regression Results of Interindustry Effects of Increases in the Minimum Wage on Employment: Dependent Variable $=\left(\Delta \mathbf{E}_{\mathrm{C}}-\Delta \mathbf{E}_{\mathrm{US}}\right)$

\begin{tabular}{|c|c|c|c|c|c|c|c|c|}
\hline & \multicolumn{2}{|c|}{ 1985-1986 } & \multicolumn{2}{|c|}{ 1986-1987 } & \multicolumn{2}{|c|}{ 1987-1988 } & \multicolumn{2}{|c|}{ 1988-1989 } \\
\hline & $\begin{array}{l}\text { OLS } \\
\text { (1) }\end{array}$ & $\begin{array}{l}\text { IV } \\
\text { (2) }\end{array}$ & $\begin{array}{l}\text { OLS } \\
\text { (3) }\end{array}$ & $\begin{array}{l}\text { IV } \\
\text { (4) }\end{array}$ & $\begin{array}{l}\text { OLS } \\
(5)\end{array}$ & $\begin{array}{l}\text { IV } \\
\text { (6) }\end{array}$ & $\begin{array}{l}\text { OLS } \\
(7)\end{array}$ & $\begin{array}{l}\text { IV } \\
\text { (8) }\end{array}$ \\
\hline Intercept & $\begin{array}{c}0.009 \\
(0.008)\end{array}$ & $\begin{array}{c}0.005 \\
(0.009)\end{array}$ & $\begin{array}{l}-0.011 \\
(0.007)\end{array}$ & $\begin{array}{l}-0.032 \\
(0.066)\end{array}$ & $\begin{array}{c}0.010 \\
(0.009)\end{array}$ & $\begin{array}{c}0.001 \\
(0.013)\end{array}$ & $\begin{array}{c}0.025^{*} \\
(0.005)\end{array}$ & $\begin{array}{c}0.028^{*} \\
(0.006)\end{array}$ \\
\hline $\begin{array}{l}\text { Coefficient } \\
\qquad\left(\Delta w_{\mathrm{C}}-\Delta w_{\mathrm{US}}\right)\end{array}$ & $\begin{array}{l}-0.364^{*} \\
(0.117)\end{array}$ & $\begin{array}{l}-0.711 \\
(0.431)\end{array}$ & $\begin{array}{l}-0.342 \\
(0.130)\end{array}$ & $\begin{array}{c}6.849 \\
(13.335)\end{array}$ & $\begin{array}{l}-0.096 \\
(0.139)\end{array}$ & $\begin{array}{l}-0.773 \\
(0.620)\end{array}$ & $\begin{array}{l}-0.851^{*} \\
(0.080)\end{array}$ & $\begin{array}{l}-0.947 * \\
(0.145)\end{array}$ \\
\hline $\mathrm{n}$ & 60 & 59 & 61 & 60 & 54 & 50 & 64 & 54 \\
\hline $\bar{R}^{2}$ & 0.13 & 0.03 & 0.09 & -0.01 & -0.01 & 0.01 & 0.64 & 0.44 \\
\hline
\end{tabular}

Source: Authors' computations based on County Business Patterns.

Notes: All regressions are weighted by employment in industry i in California. Asymptotic standard errors are given in parentheses. For the IV estimates, the instruments are mean wage and the average firm size in industry i, lagged one year.

* Significant at the 1 percent level. 
different picture emerges. In contrast to previous years, there is for this period a good fit. The 2SLS estimates of the system of equations, (3) and (5), give

$$
\begin{aligned}
\left(\Delta E_{c}-\Delta E_{u s}\right)_{i}= & 0.028-0.947\left(\Delta w_{c}-\Delta w_{u s}\right)_{i}+e_{i}, \quad \bar{R}^{2}=0.44, n=54, \\
& (0.006)(0.145) \\
\left(\Delta w_{c}-\Delta w_{u s}\right)_{i}= & 0.049-0.011 \bar{w}_{i}+0.0004 \bar{s}_{i}+e_{i}, \quad \bar{R}^{2}=0.28, n=54 \\
(0.013) & (0.004) \quad(0.0001)
\end{aligned}
$$

Our estimates of parameters in (5) suggest that, as hypothesized, between 1988 and 1989 wages increased in California (relative to the nation) more rapidly in industries where the wages were initially low and in industries where the average firm size was initially larger. The consistent IV estimates (and the OLS estimates, for that matter) of the key equation (3) are consonant with expectations: in industries within California's retail trade industry, which were forced to pay higher wages because the state's minimum wage had been raised, employment grew at a slower pace than in the country as a whole. Together, these estimates suggest that the minimum wage increase in California did have an adverse effect on employment in the low-wage retail trade industry. In this respect, the estimates support the conventional theory: wages increased in industries where the minimum wage was most likely to be binding, and in those industries where the wage did increase, the employment effect was negative.

Though our estimates of employment change in California's low-wage retail trade industry appear consistent with the predictions of the textbook model, there does remain something of a paradox. In California, from the first quarter of 1988 to the first quarter of 1989, the wage increase for workers in retail trade was more than two percentage points higher than in the rest of the country. Our estimates suggest an employment elasticity in retail trade of about -0.9. All else equal, one might 
expect employment in California's retail trade sector to have declined by about two percentage points relative to the United States. What we observe instead is that the percentage change in retail trade employment was only about half a percentage point lower in California than in the rest of the United States.

One obvious explanation is that while the increase in the minimum wage induced the expected move backward along the demand curve for labor, there was also an exogenous shift in the demand curve itself. That is, perhaps in the absence of the large increase in the minimum wage, California's low-wage employment in retail trade would have increased relative to the United States. The minimum wage increase tempered this employment growth.

This explanation is consistent with the positive intercept estimates shown in columns (7) and (8) of Table 3, but there is additional evidence to suggest that employment growth in retail sales would have been particularly high in California during this period. The Annual Report of the California State Board of Equalization indicates that taxable retail trade in California during the twelve months following the minimum wage increase (August 12, 1988, to August 11, 1989) was robust, 7.8 percent higher than in the previous twelve months. We do not have comparable data for the rest of the United States, but we can get an indication of retail sales strength from calendar-year estimates listed in the Statistical Abstract of the United States and California Statistical Abstract. These indicate that retail sales in California were 9.4 percent stronger in calendar-year 1989 than in 1988 . The percentage growth in retail sales in the rest of the United States was estimated to be just 4.9 percent.

One might argue that our labor demand equation should be specified to account for local shifts in retail trade business, and that in so doing we would improve our ability to draw inferences regarding the effects of the minimum wage. Fortunately, in the following section we are able to make some headway in this direction. 


\section{INTERCOUNTY EFFECTS OF THE MINIMUM WAGE}

California is a large and diverse state. Prior to the imposition of the new wage floor, there was substantial variation across California's fifty-eight counties in the average wages paid by retail trade employers. Thus it is not surprising that the increase in the minimum had substantially different effects in different counties. Consider San Francisco and Sutter Counties, for instance. Tax data indicate that these counties had comparable strength in retail sales growth from the twelve months preceding the minimum wage increase to the subsequent twelve-month period--Sutter County taxable sales increased by 7.2 percent, while San Francisco County taxable sales increased by 6.9 percent. San Francisco County, though, in the first quarter of 1988 had the highest average wages in retail trade

of any county in California. Here, the average wage grew by only 1.7 percent from the first quarter of 1988 to the first quarter of 1989 , suggesting that the minimum wage increase had little bite. County retail trade employment grew rapidly, by 8.0 percent. In contrast, Sutter County, an initially lower wage county, had a 9.2 percent increase in average retail trade wages and a change in retail trade employment of -2.1 percent.

These two counties present extremes, but the basic pattern is clear among California's counties: for counties with similar strength in retail sales, there appears to be a strong negative correlation between the changes in the county's retail trade wages and employment.

We pursue this observation more formally by specifying the following demand equation for county $j$ employment:

$$
\Delta E_{j}=\delta_{0}+\delta_{1} \Delta w_{j}+\delta_{2} \Delta R_{j}+u_{j}
$$

where $\Delta E_{\mathrm{j}}$ is the percentage change in the county's retail sector employment, $\Delta w_{\mathrm{j}}$ is the corresponding percentage change in the wage, and $\Delta R_{\mathrm{j}}$ is the percentage change in retail sales. In general, estimates 
of this equation will be nonsensical. Employment changes depend, presumably, on local supply and demand, and any correlation between the wage change and employment change is the result of the interaction of these two. As we argued above, though, for a year when there is an exogenous increase in the minimum, a second equation holds:

$$
\Delta w_{j}=\theta_{0}+\theta_{1} \bar{w}_{j}+\theta_{2} \bar{s}_{j}+v_{j}
$$

where $\bar{w}_{j}$ is the average wage in the county and $\bar{s}_{j}$ is the average firm size. For such a year, 2SLS of (6) and (7) will result in consistent estimates of our parameters.

Table 4 presents estimates of the key equation (6) for the years 1985-86, 1986-87, 1987-88, and 1988-89. As in our industry regressions, data on retail trade employment and pay per person are from County Business Patterns. We have these data for all but one (the smallest) of the fifty-eight counties in California. For our measure of retail sales growth, $\Delta R_{\mathrm{j}}$, we use August-to-August county retail trade data based on sales tax information. (For example, in the 1985-86 regression, we use the percentage change in taxable retail sales in the county from the twelve-month period, August 1984 through August 1985, to August 1985 through August 1986.) The results for 1985-86, 1986-87, and 1987-88 are just as anticipated: IV estimates of the coefficient on $\Delta w_{\mathrm{j}}$ are not significantly different from zero. For 1988-89 a different picture emerges. Having conditioned on retail sales growth, we find a strong negative correlation between county wage change and employment change.

Because the regressions we present are weighted by the retail employment in the county, readers may wonder about the extent to which the results are being driven by a few large counties. If we use unweighted 2SLS instead, though, we find qualitatively similar results for 1988-89. Also, the use of average firm size may be harder to justify on theoretical grounds in our county analysis than in 
TABLE 4

Regression Results of Intercounty Effects of Increases in the Minimum Wage on Employment: Dependent Variable $=\Delta \mathbf{E}$ in County $\mathbf{j}$

\begin{tabular}{|c|c|c|c|c|c|c|c|c|}
\hline & \multicolumn{2}{|c|}{$1985-1986$} & \multicolumn{2}{|c|}{ 1986-1987 } & \multicolumn{2}{|c|}{$1987-1988$} & \multicolumn{2}{|c|}{ 1988-1989 } \\
\hline & $\begin{array}{l}\text { OLS } \\
\text { (1) }\end{array}$ & $\begin{array}{l}\text { IV } \\
\text { (2) }\end{array}$ & $\begin{array}{l}\text { OLS } \\
(3)\end{array}$ & $\begin{array}{l}\text { IV } \\
\text { (4) }\end{array}$ & $\begin{array}{l}\text { OLS } \\
(5)\end{array}$ & $\begin{array}{l}\text { IV } \\
\text { (6) }\end{array}$ & $\begin{array}{l}\text { OLS } \\
\text { (7) }\end{array}$ & $\begin{array}{l}\text { IV } \\
(8)\end{array}$ \\
\hline Intercept & $\begin{array}{c}0.022 \\
(0.006)\end{array}$ & $\begin{array}{c}0.036 \\
(0.053)\end{array}$ & $\begin{array}{c}0.001 \\
(0.009)\end{array}$ & $\begin{array}{l}-0.030 \\
(0.026)\end{array}$ & $\begin{array}{l}-0.002 \\
(0.012)\end{array}$ & $\begin{array}{l}-0.001 \\
(0.014)\end{array}$ & $\begin{array}{c}0.017 \\
(0.008)\end{array}$ & $\begin{array}{c}0.017 \\
(0.012)\end{array}$ \\
\hline $\begin{array}{c}\text { Coefficient } \\
\text { on } \Delta w \mathrm{j}\end{array}$ & $\begin{array}{l}-0.048 \\
(0.117)\end{array}$ & $\begin{array}{c}1.845 \\
(1.544)\end{array}$ & $\begin{array}{c}0.028 \\
(0.163)\end{array}$ & $\begin{array}{c}1.369 \\
(0.973)\end{array}$ & $\begin{array}{l}-0.015 \\
(0.111)\end{array}$ & $\begin{array}{l}-0.100 \\
(0.331)\end{array}$ & $\begin{array}{l}-0.732 * \\
(0.103)\end{array}$ & $\begin{array}{l}-0.743^{*} \\
(0.219)\end{array}$ \\
\hline $\begin{array}{c}\text { Coefficient } \\
\text { on } \Delta \mathrm{Rj}\end{array}$ & $\begin{array}{c}0.612^{*} \\
(0.121)\end{array}$ & $\begin{array}{l}-0.122 \\
(0.657)\end{array}$ & $\begin{array}{c}0.773^{*} \\
(0.134)\end{array}$ & $\begin{array}{c}0.985^{*} \\
(0.250)\end{array}$ & $\begin{array}{c}0.454^{*} \\
(0.159)\end{array}$ & $\begin{array}{c}0.463^{*} \\
(0.163)\end{array}$ & $\begin{array}{c}0.686^{*} \\
(0.092)\end{array}$ & $\begin{array}{c}0.689^{*} \\
(0.105)\end{array}$ \\
\hline $\mathrm{n}$ & 57 & 57 & 57 & 57 & 57 & 57 & 57 & 57 \\
\hline $\bar{R}^{2}$ & 0.32 & 0.07 & 0.37 & 0.21 & 0.10 & 0.10 & 0.59 & 0.42 \\
\hline
\end{tabular}

Source: Authors' computations based on County Business Patterns.

Notes: All regressions are weighted by employment in county j. Asymptotic errors are given in parentheses. For the IV estimates, the instruments are mean wage in county $\mathrm{j}$ and the average firm size in county $\mathrm{j}$, lagged by one year.

* Significant at the 1 percent level. 
the industry analysis presented in the previous section. If instead we use just the county wage (lagged by one year) as our instrument, the results are again little changed.

We thus find that California's 1988 minimum wage increase looks nearly the same from two different angles. In the preceding section we showed that in retail trade industries where the wage grew rapidly in California as a result of the increase in the minimum wage, employment was adversely affected. In this section we find that in counties where retail trade wages increased due to the minimum wage boost, county employment growth in retail trade was tempered. Moreover, our consistent IV estimator (see column (8) of Table 4) suggests an employment elasticity, -0.7 , in the same range as the elasticities presented in the previous section.

\section{CONCLUSION}

One of the most direct and compelling applications of conventional theory to public policy is the prediction that an increase in the minimum wage reduces employment in competitive markets. Empirical findings to the contrary perhaps suggest that labor economists should more carefully consider noncompetitive models that pertain to low-wage labor markets, and in any event indicate a reassessment of our predictions about the welfare consequences of minimum wage laws.

Because the 1988 California minimum wage increase represents an excellent opportunity to empirically evaluate the effects of minimum wages, and because of Card's (1992a) important and surprising finding that this minimum wage increase had no effect on teen employment, we have undertaken in this paper to further investigate the effects of the minimum wage increase on the low-wage retail trade industry. We noticed first that the increase in wages in California's retail trade (from the first quarter of 1988 to the first quarter of 1989) was more than two full percentage points higher than in the rest of the United States, due, we suppose, to the increase in California's minimum 
wage. We then showed that within industries in retail trade there is a strong negative correlation between the relative wage changes and employment growth. IV estimates suggest an elasticity of employment with respect to wages of about -0.9 .

We also explored the effect of the minimum wage increase by examining intercounty variation in the wage change in retail trade and the corresponding employment change. Again we found a strong negative correlation and a wage elasticity for retail trade employment in the neighborhood of -0.7 .

We are thus in the fortunate position of having found a natural experiment that demonstrates with unusual clarity the effect of a minimum wage increase. Two approaches to evaluating the experiment lead to the similar conclusions, and in both instances the results are apparent as obviously significant coefficients in simple regressions. Our results reject the null hypothesis that minimum wage increases have no effect on employment. ${ }^{10}$ 


\section{Notes}

${ }^{1}$ Although the federal minimum wage remained constant through most of the 1980s, several states passed minimum wage laws raising the state minimum to levels above the national standard.

${ }^{2}$ William Spriggs (1992) reported similar results in his study of the fast-food industry. Using panel data from 1977-89, David Neumark and William Wascher (1992) found that increases in the minimum wage adversely affected teenage employment, but subsequent work by Card, Katz, and Krueger (1993) argued that the key results of Neumark and Wascher were due to error in the authors' estimation procedures and analysis. Charles Brown (1988) and Brown, Gilroy, and Cohen (1982) overview previous literature.

${ }^{3} \mathrm{~A}$ monopsony model is one well-known example where increases in the minimum can increase employment (e.g., Stigler, 1946). James Rebitzer and Lowell Taylor (1991) show that monopsony-like results can pertain even in a labor market with many employers when those employers use efficiency wages.

${ }^{4}$ These data are tabulated from universe files, so sampling error is not an issue, though of course non-sampling error is still a potential problem. From our perspective, the biggest shortcoming in the data is that we do not observe wages, only average pay per person. Whenever we refer to the "wage" in our paper, we are referring, unfortunately, to this less precise measure.

${ }^{5}$ As an alternative way of examining the wage growth in California as compared to that in the United States, we computed the average reported wage for "hourly paid workers" in the CPS for the periods September 1987-May 1988 for both California and the United States. We found that in California the average wage increased 6.58 percent from the former to the latter period, while in the rest of the United States the average wage increased by 3.67 percent. Note that these figures do not differ greatly from the corresponding figures listed in the last column of Table 1. 
${ }^{6}$ In forty-three states and in the District of Columbia, the minimum wage did not change, and in states where the minimum did increase, the increments were more modest than California's $\$ 0.90$ increase. The minimum increased during this period in Connecticut, Minnesota, and Washington by $\$ 0.50$, in Pennsylvania by $\$ 0.35$, and in Maine, New Hampshire, and Massachusetts by $\$ 0.10$. One possible research design would be to follow Card (1992a) and form a "control" group from a group of states where the minimum wage did not change at all, and where previous employment growth was similar to that in California. Using the $C B P$ data for retail trade employment, we found that employment trends were more similar in California and the United States as a whole than in California and the southern and southwestern states Card examined.

${ }^{7}$ California's law allowed for a lower minimum for teenagers and for some apprentices and job learners (see Card, 1992a).

${ }^{8}$ Given that our "wage" is constructed by dividing payroll by employment for each industry, $\bar{w}_{i}$ will be correlated with $E_{\mathrm{i}}$ in any period if $E_{\mathrm{i}}$ is measured with error. This would make $\bar{w}_{i}$ an inappropriate instrument for $\Delta w_{\mathrm{i}}$. To resolve this problem we use for each industry $\bar{w}_{t-2}$ as our instrument for $\Delta w=w_{\mathrm{t}}-w_{\mathrm{t}-1}$. For similar reasons, the instrument for firm size is also constructed using values of $E_{\mathrm{i}}$ lagged one year.

${ }^{9}$ Between 1987 and 1988, there was some shuffling of the SIC codes. To match SIC codes between 1987 and 1988, several 3-4 digit sectors were omitted. (These omitted sectors represent 2.2 percent of total employment in retail trade.) This accounts for the differing sample sizes in our regressions.

${ }^{10}$ Careful work needs to be done if these results are to be properly translated into welfare analysis, and we do not pursue this track here. For example, elsewhere we argue that the results of this paper are not necessarily inconsistent with low-wage firms paying efficiency wages, as suggested, for 
example, in the work of Holtzer, Katz, and Krueger (1991). Indeed, part of the reason that growth in retail trade employment did not fall by even more may have been due to efficiency wage

considerations. Such issues, if relevant, need to be explored using firm-level data. In any event, they should not be ignored in a detail welfare evaluation. 


\section{References}

Ashenfelter, Orley, and Robert Smith. 1979. "Compliance with the Minimum Wage Law." Journal of Political Economy 87(2): 333-350.

Brown, Charles. 1988. "Minimum Wage Laws: Are They Overrated?" Journal of Economic Perspectives 2(3): 133-145.

Brown Charles, Curtis Gilroy, and Andrew Kohen. 1982. "The Effect of the Minimum Wage on Employment and Unemployment." Journal of Economic Literature 20: 487-528.

California Department of Finance. Various years. California Statistical Abstract. Sacramento, Calif.

California State Board of Equalization. Various years. Annual Report. Sacramento, Calif.

Card, David. 1992a. "Do Minimum Wages Reduce Employment? A Case Study of California, 1987-89." Industrial and Labor Relations Review 46: 38-54.

Card, David. 1992b. "Using Regional Variation in Wages to Measure the Effects of the Federal Minimum Wage." Industrial and Labor Relations Review 46: 22-37.

Card, David, Lawrence Katz, and Alan Krueger. 1993. "Comment on David Neumark and William Wascher, 'Employment Effects of Minimum and Subminimum Wages: Panel Data on State Minimum Wage Laws.’" Working Paper no. 316, Industrial Relations Section, Princeton University.

Card, David, and Alan Krueger. 1993. "Minimum Wages and Employment: A Case Study of the Fast Food Industry in New Jersey and Pennsylvania." Working paper, Princeton University.

Holtzer, Harry, Lawrence Katz, and Alan Krueger. 1991. "Job Queues and Wages." Quarterly Journal of Economics 106: 739-768.

Katz, Lawrence, and Alan Krueger. 1992. "The Effect of the Minimum Wage on the Fast-Food Industry." Industrial and Labor Relations Review 46: 6-21. 
Neumark, David, and William Wascher. 1992. "Employment Effects of Minimum and Subminimum Wages: Panel Data on State Minimum Wage Laws." Industrial and Labor Relations Review 46: $55-81$.

Rebitzer, James B., and Lowell J. Taylor. 1991. "The Consequences of Minimum Wage Laws: Some New Theoretical Ideas." NBER Working Paper no. 3877.

Spriggs, William E. 1992. "The Effects of Changes in the Federal Minimum Wage: Restaurant Workers in Mississippi and North Carolina." Draft, Economic Policy Institute, Washington, D.C.

Stigler, George. 1946. "The Economics of Minimum Wage Legislation." American Economic Review 36: $358-365$.

U.S. Department of Commerce, Bureau of the Census. Various years. County Business Patterns. Washington, D.C.

U.S. Department of Commerce, Bureau of the Census. Various years. Statistical Abstract of the United States. Washington, D.C.: U.S. Government Printing Office. 